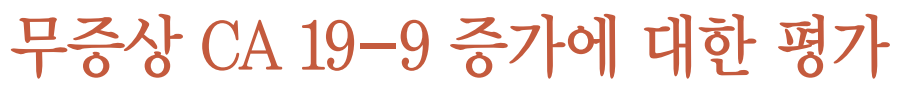

서울대학교 의과대학 분당서울대학교병원 내과

김재환

\title{
Assessment of Asymptomatically Increased CA 19-9
}

\author{
Jaihwan Kim \\ Department of Internal Medicine, Seoul National University Bundang Hospital, Seoul National University College of Medicine, Seongnam, Korea
}

Health care screening is becoming more popular in Korea as more people are interested in well-being and health. However, there are controversies regarding usefulness of screening. Tumor markers are frequently measured in the health care screening. As a result, many patients end up visiting physicians because of incidentally found increased levels of tumor markers. Carbohydrate antigen (CA) 19-9 is the single most useful tumor marker for pancreatic cancer. Although CA 19-9 is useful for predicting prognosis and evaluating treatment response for pancreatic cancer, CA 19-9 is less useful for screening of pancreatic cancer because of low incidence of pancreatic cancer.

Korean J Pancreas Biliary Tract 2017;22(3):114-117

Keywords: Pancreatic neoplasms, Biomarkers, Tumor, Early detection of cancer, CA 19-9 antigen

\author{
Received Apr. 30, 2017 \\ Revised Jun. 3,2017 \\ Accepted Jun. 5, 2017
}

Corresponding author : Jaihwan Kim

Department of Internal Medicine, Seoul National University Bundang Hospital, Seoul National University College of Medicine, 82, gumi-ro 173 beon-gil, Bundang-gu, Seongnam 13620, Korea Tel. +82-31-787-7075 Fax. +82-31-787-4290 E-mail; drjaihwan@snu.ac.kr

\section{서 론}

종양 표지자는 신체에서 채취 혹은 분비되는 검체의 수치를 측정하여 악성 종양의 진단과 치료에 사용하는 검사 수단이 다. 이와 같은 종양 표지자는 이론적으로 악성 종양의 조기 진 단을 위한 선별 검사, 악성 종양 진단의 보조 수단, 예후의 예 측, 재발의 예측 그리고 치료 약제에 대한 반응 혹은 내성에 대 한 지표 등에 이용 될 수 있다. 종양 표지자 중 잘 알려진 것으 로는 조기 대장암 선별 검사에 사용되는 대변 잠혈 검사, 대장 직장암 환자 치료에 사용되는 carcinoembryonic antigen (CEA), 비생식세포양 배아세포종양(nonseminomatous germ cell tumors) 치료에서의 $\alpha$-태아단백( $\alpha$-fetoprotein)과 인간 융 모막 생식샘자극호르몬(human chorionic gonadotrophin, $\mathrm{hCG}$ ), 난소암 치료의 지표인 탄수화물 항원 125 (carbohydrate antigen 125, CA 125), 유방암에서 호르몬 치료에 대한 반응 예측에 사용되는 에스트로겐 수용체(estrogen receptor), 유방암 및 위암에서 trastuzumab (Herceptin ${ }^{\circledR}$; Genentech, CA, USA) 치료에 대한 반응을 예측하기 위한 인간 표피 성장 인자 수용체 2 (epidermal growth factor receptor 2, EGFR 2) 그리고 췌장암 치료의 지표인 탄수화물 항원 19-9 (carbohydrate antigen 19-9, CA 19-9) 등이 있다.

이번 논고에서는 췌장암에서 유일하게 임상적으로 입증되 
어 사용되고 있는 종양 표지자 CA 19-9의 역할 중 무증상 CA 19-9 증가의 임상적 의미와 그에 대한 해석에 대해 살펴보고 자 한다.

\section{본 론}

CA 19-9는 인간 대장 세포주 SW1116에 면역된 쥐에서 분 리된 단클론 항체(monoclonal antibody)를 이용하여 발견한 고분자량의 당지질이다. ${ }^{2} \mathrm{CA}$ 19-9는 정상적으로 췌장 및 담도 계에서 합성되며, 그 외 위, 대장, 자궁 내막, 침샘 상피세포 등 에서도 합성되어 분비되고 반감기는 $4-8$ 일이다. ${ }^{3}$ 정상 췌장에 서 CA 19-9는 큰 췌관의 관세포 꼭대기에 주로 존재하며, 꽈리 샘이나 랑게르한스 세포에는 존재하지 않는다. CA 19-9는 다 른 종양 표지자들처럼 점액 당단백에 의해 혈청에서 운반되 며, CA 19-9의 정상 참고치 범위는 $37 \mathrm{U} / \mathrm{mL}$ 미만이다. ${ }^{2}$ 한편, 초기 췌장암이나 혹은 Lewis 항원 음성인 환자에서는 CA 19-9 값이 상승하지 않는다고 알려져 있다.

발견 초기 CA 19-9는 직장대장암에서 이용되었으나, 현재 는 위장관 악성 종양보다는 췌장암에서 가장 흔하게 이용되고 있다. 췌장암에서 CA 19-9의 정상 범위를 $37 \mathrm{U} / \mathrm{mL}$ 라고 하였 을 때 정상 췌장 또는 췌장암을 제외한 다른 췌장질환과의 감 별 능력은 민감도 $70-90 \%$, 특이도 $68-91 \%$ 라고 알려져 있다 (Table 1). ${ }^{5,6}$ 이와 같이 CA 19-9는 비교적 채택할 만할 정도의 진단 능력에도 불구하고 무증상의 건강한 사람들을 위한 대 상으로 한 선별 검사로서는 적절하지 않다. ${ }^{7}$ 이는 검사의 양성 예측도(검사에서 양성 소견일 경우 질환이 있을 확률)가 낮기 때문인데, 양성 예측도를 구하는 공식은 다음과 같다.

$$
P P V=\frac{\text { sens }}{\operatorname{sens}+(1-\operatorname{spec}) *(1 / \text { prev }-1)}
$$

비록 우리 나라에서 췌장암의 공식적인 유병률은 알려져 있 지 않으나, 1999년도 국가건강보험자료에 따르면 30세 이상의 성인에서 10 만 명당 약 13.66 명이라고 보고된 바 있다. ${ }^{8}$ 이에 CA 19-9를 이상적인 검사로 가정하여 민감도와 예민도를 각
각 0.99라고 하였을 때 양성 예측도는 약 0.01로 이는 CA 19-9 $>37 \mathrm{U} / \mathrm{mL}$ 인 100 명의 검사자 중 1 명이 췌장암 환자임을 의미 한다. 만약 CA 19-9의 민감도와 예민도를 앞서 언급한 바와 같 이 실제 현실에서의 값인 0.80 및 0.90 이라고 하면 같은 조건에 서 양성예측도는 약 0.0008 이며 이는 CA $19-9>37 \mathrm{U} / \mathrm{mL}$ 인 10,000 명의 검사자 중 8 명만이 췌장암 환자라는 뜻이다. 따라 서 무증상 CA 19-9 증가 환자의 대부분은 췌장암 환자가 아닐 것으로 예측할 수 있다.

이와 같은 이론적인 예측에 대해 실제 현실에서 무증상 $\mathrm{CA}$ 19-9 상승은 어떤 의미가 있는지에 대해서 일본과 한국에서 발표한 연구가 있었다. 무증상 CA 19-9 상승에 대한 첫 번째 연구는 Homma 와 Tsuchiya에 의해 일본에서 발표되었다. ${ }^{9}$ 연 구자들은 무증상 10,162 명의 대상자를 상대로 CA 19-9와 elastase 1 을 측정하거나 혹은 복부 초음파 검사를 시행하였고 두 가지 검사(CA 19-9 + elastase 1 또는 복부 초음파) 중 하나 라도 이상이 있는 경우 추가적인 검사를 시행하였다. 그 결과 전체 10,162 명의 대상자 중 18 명 $(0.2 \%)$ 에서 CA 19-9 상승이 발견되었고, 820 명 $(8.1 \%)$ 에서 한 가지 이상 검사 이상이 발견 되었다. 그중 793명을 대상으로 복부 전산화단층촬영, 역행성 담췌관조영술, 혈관조영술 등의 추가적인 검사를 시행하였을 때 악성 종양은 8 명 $(1.0 \%, 8 / 793)$ 이었고 췌장암은 4 명 $(0.5 \%$, 4/793)이었다. 그에 비해 연구자들은 같은 방법으로 복통 또는 황달 등 증상이 있는 4,506 명의 환자를 대상으로 같은 프로토 콜의 연구를 진행하였을 때 CA 19-9 상승은 196명(4.3\%)이었 고, 두 가지 검사 중 한 가지 이상이 발견된 환자는 2,037명 (45\%)이었다. 이 중 1,584 명에서 추가 검사를 시행하였을 때 악성 종양은 158 명 $(10.0 \%, 158 / 1,584)$ 이었고 췌장암은 85 명 $(5.4 \%, 85 / 1,584)$ 이었다. 그 결과 저자들은 증상이 없는 건강 한 사람을 대상으로 한 췌장암의 조기 발견을 위한 선별 검사 는 의미가 없으며, 증상을 동반한 환자에서의 선별 검사만이 유용하다고 결론을 내렸다.

CA 19-9 상승의 선별 검사로서 역할에 대한 다른 두 연구는 우리나라에서 이루어졌다. 이 중 첫 번째 연구는 $\mathrm{Kim}$ 등 $^{10}$ 에 의해 1994년 12월과 2000년 11월 사이의 70,940명 건강검진 수

Table 1. Sensitivity and specificity of CA 19-9 in diagnosis of pancreatic cancer

\begin{tabular}{lcccc}
\hline Tumor marker & Author & Sensitivity & Specificity & Number of patients \\
\hline CA 19-9 & Steinberg $^{5}$ & 81 & 90 & 1,040 \\
& Goonetilleke and Siriwardena $^{6}$ & 79 & 82 & 2,283 \\
\hline
\end{tabular}

CA 19-9, carbohydrate antigen 19-9. 
진자 결과를 이용해 보고되었다. 연구자들에 따르면 70,940명 중 1,063명 $(1.5 \%)$ 에서 CA $19-9>37 \mathrm{U} / \mathrm{mL}$ 이상이 발견되었 는데 이 중 38-100 U/mL의 상승을 보인 수진자는 982명이었 고 $100 \mathrm{U} / \mathrm{mL}$ 이상의 상승을 보인 수진자는 81 명이었다. 이 중 982명의 CA 19-9 $\leq 100 \mathrm{U} / \mathrm{mL}$ 인 경우에서는 악성 종양 환자 가 없었으나 CA 19-9 > $100 \mathrm{U} / \mathrm{mL}$ 인 81명 중 15명 $(19 \%$, $15 / 81)$ 에서 악성 종양이 발견되었고, 그중 췌장암은 4 명 $(5 \%$, 5/81)에서 발견되었다. 그 결과 저자들은 무증상 대상자에서 CA 19-9를 이용한 췌장암의 선별 검사는 낮은 양성예측도를 감안할 때 효율적이지 않다고 결론을 내렸다. 같은 연구자들 에 의한 두 번째 연구는 동일 건강검진기관에서 2004년 1월과 2007년 3월 사이 건강검진을 시행받은 62,976명을 대상으로 이루어졌다. ${ }^{11}$ 저자들은 CA $19-9>37 \mathrm{U} / \mathrm{mL}$ 이상인 수진자를 대상으로 CA 19-9를 한번 더 검사하였고, 그 결과 한 번의 검 사에서 상승한 수진자는 825 명 $(1.3 \%)$, 두 번의 검사에서 모두 상승한 경우는 501 명 $(0.8 \%)$ 이었다. 이 중 353 명 $70.5 \%$, $363 / 501)$ 에게서 6 개월 이상의 추적과 복부 전산화단층촬영술 이 시행되었다. 복부 전산화단층촬영술에서 이상소견이 있는 수진자는 내시경역행성담췌관조영술, 자기공명담췌관조영 술, 양전자방출 단층촬영술 등의 추가 검사를 시행하였고, 복 부 전산화단층촬영술에서 이상소견이 없었던 수진자는 CA $19-9$ 를 $1,3,6$ 개월에 재시행하였고 지속적으로 상승한 경우에 는 추가 검사, 감소 혹은 정상인 경우에는 추적 검사만 시행하 였다. 그 결과 353 명 중 10 명 $(2.8 \%, 10 / 353)$ 에서 악성 종양이 발견되었고 이 중 4 명 $(1.1 \%, 4 / 353)$ 에서 췌장암이 발견되었다. 한편 이 연구에서 주목해야 할 점은 4 명의 췌장암 환자 중 한 명은 수술이 불가능한 4기로 발견되었다는 점으로, CA 19-9 의 상승으로 비교적 여러 번 검사를 받았는데도 불구하고 진 행성 병기로 췌장암이 발견되었다는 점은 눈여겨보아야 할 듯 하다. 이와 같은 결과를 바탕으로 저자들은 CA 19-9는 선별 검사로는 사용되지 말아야 하며, CA 19-9가 지속적으로 상승 한 경우에만 원인 파악을 위한 추가적인 검사가 이루어져야 한다고 주장하였다.

한편, CA 19-9는 췌장암 외에 방광암 환자와 대장직장암 환 자에서도 상승될 수 있으며, 그 외 다른 소화기계 악성 종양 (예를 들면, 위암 또는 담도계암)에서도 상승할 수 있고, 갑상 선질환, 류마티스 관절염, 염증성 대장질환, 췌장염 그리고 담 관염 등에서도 상승할 수 있다고 알려져 있다. 그런가 하면 CA 19-9의 진단적인 가치는 폐쇄성 황달이 있을 경우에는 제 한적인데, 이는 폐쇄성 황달이 있는 환자의 $28 \%$ 에서 CA $19-9$
상승이 보고되었기 때문이다. ${ }^{2}$ 또한, CA 19-9는 점액성 낭성 종양이나 관내 유두상 점액 종양들과 같은 점액성 신생물을 양성 점액 질환으로부터 구별하는데 제한적이다. ${ }^{12}$

\section{결 론}

췌장암은 예후가 매우 좋지 않은 악성 종양으로 수십 년간 치료 성적의 개선은 제한적이었다. 이를 개선하기 위해서는 췌장암의 조기 발견, 진단, 예후 예측을 위한 종양 표지자가 이 상적이나 현재까지 만족스러운 종양 표지자는 없는 실정이다. CA 19-9는 췌장암에서 예후를 예측하고 치료 과정을 추적하 는 유일하고도 유용한 종양 표지자이긴 하지만 췌장암의 낮은 발생률로 인해 무증상 건강한 사람에게서 우연히 발견된 CA 19-9의 상승만으로 췌장암을 의심하는 것은 제한이 있다. 따 라서 환자가 특별한 증상이나 다른 위험인자가 없다면 지속적 인 상승을 보이는 경우에만 추가 검사를 시행해 보는 것이 합 리적일 것이다.

\section{요 약}

많은 사람들이 복지 및 건강에 대한 관심이 증가하면서 한 국에서 건강검진은 점점 더 많이 행해지고 있다. 하지만 건강 검진의 유용성에 대해서는 논란이 있다. 종양 표지자는 건강 검진에서 흔히 행해지게 되는데 그 결과 많은 환자들이 우연 히 발견된 종양 표지자의 상승으로 병원을 방문하게 된다. CA 19-9는 췌장암에서 예후를 예측하고 치료 과정을 추적하는데 유용한 종양 표지자지만 췌장암의 낮은 발생률로 인해 췌장암 의 선별 검사로서는 유용성이 떨어진다.

국문 색인: 췌장암, 종양 표지자, 암의 조기 진단, 암항원 19-9

\section{Conflicts of Interest}

The author has no conflicts to disclose.

\section{REFERENCES}

1. Duffy MJ. Tumor markers in clinical practice: a review focusing on common solid cancers. Med Princ Pract 2013;22:4-11.

2. Eskelinen M, Haglund U. Developments in serologic detection of human 
pancreatic adenocarcinoma. Scand J Gastroenterol 1999;34:833-844.

3. Rhodes JM, Ching CK. Serum diagnostic tests for pancreatic cancer. Baillieres Clin Gastroenterol 1990;4:833-852.

4. Herlyn M, Sears HF, Steplewski Z, Koprowski H. Monoclonal antibody detection of a circulating tumor-associated antigen. I. Presence of antigen in sera of patients with colorectal, gastric, and pancreatic carcinoma. J Clin Immunol 1982;2:135-140.

5. Steinberg $W$. The clinical utility of the CA 19-9 tumor-associated antigen. Am J Gastroenterol 1990;85:350-355.

6. Goonetilleke KS, Siriwardena AK. Systematic review of carbohydrate antigen (CA 19-9) as a biochemical marker in the diagnosis of pancreatic cancer. Eur J Surg Oncol 2007;33:266-270.

7. Swords DS, Firpo MA, Scaife CL, Mulvihill SJ. Biomarkers in pancreatic adenocarcinoma: current perspectives. Onco Targets Ther 2016;9:7459-7467.

8. National Health Insurance Service. National Health Insurance Statistical
Yearbook. Seoul: National Health Insurance Service, 2005.

9. Homma T, Tsuchiya R. The study of the mass screening of persons without symptoms and of the screening of outpatients with gastrointestinal complaints or icterus for pancreatic cancer in Japan, using CA19-9 and elastase-1 or ultrasonography. Int J Pancreatol 1991;9:119-124.

10. Kim JE, Lee KT, Lee JK, Paik SW, Rhee JC, Choi KW. Clinical usefulness of carbohydrate antigen 19-9 as a screening test for pancreatic cancer in an asymptomatic population. J Gastroenterol Hepatol 2004;19:182186.

11. Kim BJ, Lee KT, Moon TG, et al. How do we interpret an elevated carbohydrate antigen 19-9 level in asymptomatic subjects? Dig Liver Dis 2009;41:364-369.

12. Tanaka M, Chari S, Adsay V, et al. International consensus guidelines for management of intraductal papillary mucinous neoplasms and mucinous cystic neoplasms of the pancreas. Pancreatology 2006;6:17-32. 